\title{
Discussion: Experience of the role of contracts in megaproject execution
}

Paul E. Jobling BSC, MSc, CEng, MICE, MAPM

Specialist Consultant, Kingsfield Consulting International, Surrey, UK

Nigel J. Smith BSC, MSc, PhD, CEng, FICE, FCIHT, FAPM, FHEA Professor of Project and Transport Infrastructure Management, Member of the Institute for Resilient Infrastructure and Head of Project Management Group, School of Civil Engineering, University of Leeds, Leeds, UK

\section{Contribution by Francisco del Rey}

The contributor thanks the Institution of Civil Engineers (ICE) for the publication of the paper 'Experience of the role of contracts in megaproject execution' (Jobling and Smith, 2018) in the Proceedings of the Institution of Civil Engineers - Management, Procurement and Law. The contributor found the paper well written and relevant to the industries in which KBR operates.

The authors rightly discuss typical risks of megaprojects that lead to underperformance. They focus on the constraints potentially imposed by contracts and contractual relationships and their impact on the execution of projects. Crucially they conclude that '[a] pragmatic approach would be to seek to match more closely the approaches between the, often conflicting, legal and contractual requirements and the most appropriate tools and techniques' (Jobling and Smith, 2018: p. 23).

In the contributor's experience, he feels that this is the area where megaprojects can deliver major improvements. Prime contractors are ideally placed to see how risks are managed, or not, and flow down on this sort of project. There are some indications that the typical relationships established between a company and contractors on megaprojects may not suit the execution of megaprojects. The success of megaprojects is intrinsically linked to the management of risks. The current business environment does not allow for risks to be unmitigated, but the typical mitigation strategy is to pass the risk contractually to another party on the project. While the contributor concurs with the views of some of the literature on the complexity introduced by New Engineering Contract (NEC) contracts, NEC has brought to the fore the need for risks to be managed jointly (early warnings) rather than being shifted on to one of the parties.

The contributor found the statistical analysis of alliancing on projects very interesting. While he believes that a more quantitative analysis is required to draw any conclusions on the suitability of alliancing on megaprojects, he feels that a natural line of follow-on research is a better integration of the supply chain into the delivery of megaprojects. Contracts will no doubt be the vehicle to formalise this improved integrated structure, but it is the better integration of all parties that will deliver the real benefits.
Francisco del Rey PhD, MSc, MEng

Director, Procurement and Materials, KBR, Leatherhead, UK

The contributor is interested to follow these ideas up with the authors.

\section{Authors' reply}

The contributor's comments confirm that management of risk is paramount in the management of megaprojects and, in the experience of the authors, of all projects.

It is true that the NEC encourages a more open and collaborative approach to the identification, discussion and management of risk. However, this runs contrary to the reported developments in the commonly used International Federation of Consulting Engineers suite of contracts and derivatives thereof which, as the authors note, tend to pass even more risk to the contractors and their supply chains without facilitating better integration of all the parties. It appears that owners prefer to transfer risk to contractors, and this is a legitimate and understandable position. On the other hand, wholesale transfer of risk may be ineffective, be damaging to project success and militate against openness and collaboration.

It is true that the choice of contract is not, in itself, a choice to be confrontational, but it appears that the allocation of risk under the traditional forms of contracts makes collaboration less rather than more likely. The NEC and its earlier form, the Engineering and Construction Contract, have existed and have been in use for around 20 years, but the majority of owners and their advisors have not yet adopted these. The precise reasons for this are unknown, nor is the correlation, if any, between contract type and project success understood. Both of these matters warrant further research.

With respect to alliancing, there is acknowledgement in various publications over the last 12 months that existing model(s) for the implementation of construction projects is unsatisfactory. The ICE publication From Transactions to Enterprises (ICE Infrastructure Client Group, 2017) suggests that the interests of owners and suppliers need to be more closely aligned with the commercial arrangements between the parties reflecting these rather than owners using highly transactional contracts to secure their objectives, including, in many cases, the maximum transfer of risk and lowest initial price as their measure of value for money. 
The McKinsey Global Institute (2017) report Reinventing Construction: a Route to Higher Productivity also suggests that alliancing is a benefit and delivers better results than traditional procurement.

Merrow's conclusions on alliancing, as reported in the authors' paper, may therefore be either specific to megaprojects and/or related specifically to the industrial plants that he studied, rather than other categories of projects.

Both the ICE and McKinsey reports suggest that greater alignment of the commercial interests of the parties is required. The ICE report also notes that significant transaction costs in traditional procurement methods need to be reduced. Similarly, the recent European Construction Institute/Construction Industry Institute event 'Rethinking how capital programmes are delivered', in Amsterdam, the Netherlands, also suggested that transaction costs must be significantly reduced to the extent that twice the number of projects could be delivered for the current total cost of one.
It should be noted that none of the reports cited earlier are related specifically to megaprojects, and given the particular characteristics of megaprojects, some of the suggestions may not be applicable to them. The fact is, however, that much more research is required to understand fully the impact of the contractual arrangements on the sanction, procurement, implementation and outcomes of megaprojects. Similarly, investigation is required to ascertain if the recent suggestions for change noted in the above sector can be beneficially applied to megaprojects.

\section{REFERENCES}

ICE (Institution of Civil Engineers) Infrastructure Client Group (2017) From Transactions to Enterprises: a New Approach to Delivering High Performance Infrastructure. ICE, London, UK.

Jobling PE and Smith NJ (2018) Experience of the role of contracts in megaproject execution. Proceedings of the Institution of Civil Engineers - Management, Procurement and Law 171(1): 18-24, https://doi.org/10.1680/jmapl.17.00006.

McKinsey Global Institute (2017) Reinventing Construction: a Route to Higher Productivity. McKinsey Global Institute, Washington, DC, USA.

\section{How can you contribute?}

To discuss this paper, please email up to 500 words to the editor at journals@ice.org.uk. Your contribution will be forwarded to the author(s) for a reply and, if considered appropriate by the editorial board, it will be published as discussion in a future issue of the journal.

Proceedings journals rely entirely on contributions from the civil engineering profession (and allied disciplines). Information about how to submit your paper online is available at www.icevirtuallibrary.com/page/authors, where you will also find detailed author guidelines. 